\title{
Impact of ohmicsonication treatment on pectinmethylesterase in not-from-concentrate orange juice
}

\author{
Abedelmaksoud, Tarek Gamal; Mohsen, Sobhy Mohamed; Duedahl-Olesen, Lene; Elnikeety, Mohamed \\ Mohamed; Feyissa, Aberham Hailu
}

Published in:

Journal of Food Science and Technology

Link to article, DOI:

10.1007/s13197-019-03834-2

Publication date:

2019

Document Version

Peer reviewed version

Link back to DTU Orbit

Citation (APA):

Abedelmaksoud, T. G., Mohsen, S. M., Duedahl-Olesen, L., Elnikeety, M. M., \& Feyissa, A. H. (2019). Impact of ohmicsonication treatment on pectinmethylesterase in not-from-concentrate orange juice. Journal of Food Science and Technology, 56(8), 3951-3956. https://doi.org/10.1007/s13197-019-03834-2

\section{General rights}

Copyright and moral rights for the publications made accessible in the public portal are retained by the authors and/or other copyright owners and it is a condition of accessing publications that users recognise and abide by the legal requirements associated with these rights.

- Users may download and print one copy of any publication from the public portal for the purpose of private study or research.

- You may not further distribute the material or use it for any profit-making activity or commercial gain

- You may freely distribute the URL identifying the publication in the public portal 


\title{
2 Impact of ohmicsonication treatment on pectinmethylesterase 3 in not-from-concentrate orange juice
}

\author{
4 Tarek Gamal Abedelmaksoud $^{1,2}$ (1) $\cdot$ Sobhy Mohamed Mohsen ${ }^{1} \cdot$ Lene Duedahl-Olesen $^{2}$ • \\ 5 Mohamed Mohamed Elnikeety ${ }^{1} \cdot$ Aberham Hailu Feyissa $^{2}$
}

Revised: 9 May 2019/ Accepted: 14 May 2019

(C) Association of Food Scientists \& Technologists (India) 2019

\begin{abstract}
The present study investigates the application of ohmicsonication (OS) as a new hurdle technology for pasteurization of Not-from-concentrate orange juice (NFCOJ). OS process parameters to inactivate pectinmethylesterase (PME) activity in NFCOJ were optimized using response surface methodology. The influence of Sonication (S), Thermosonication (TS), Ohmic heating $(\mathrm{OH})$ and $\mathrm{OS}$ on inactivation of PME were compared to conventional heat $(\mathrm{CH})$ treatment. Their effects on physical, chemical and microbiological contents were included. In comparison to fresh orange juice, the inactivation of PME was $96 \%, 95 \%, 89 \%, 90 \%$ and $29 \%$ for OS, OH, TS, $\mathrm{CH}$ and $\mathrm{S}$ treatments, respectively. Highest cloud value was obtained for OS (1.240 A) treatment. OS treatment gave a lower vitamin $\mathrm{C}$ loss compared to $\mathrm{TS}, \mathrm{OH}$ and $\mathrm{CH}$ treatments. A significant increase in the total phenolic content were obtained in the following order OS $>$ TS $>$ $\mathrm{OH}>\mathrm{CH}$. OS treated juice also contained the lowest value of hydroxymethyl furfural $(0.90 \mathrm{mg} / \mathrm{L})$ compared to $\mathrm{OH}$ $(0.95 \mathrm{mg} / \mathrm{L}), \mathrm{TS}(1.37 \mathrm{mg} / \mathrm{L})$ and $\mathrm{CH}(2.72 \mathrm{mg} / \mathrm{L})$ treated samples. Overall, the results indicated that OS can be Q1 integrated as a substitute to pasteurization of NFCOJ.
\end{abstract}

A1

A2

A3

A4

A6
Electronic supplementary material The online version of this article (https://doi.org/10.1007/s13197-019-03834-2) contains supplementary material, which is available to authorized users.

Tarek Gamal Abedelmaksoud

tareekgamal_88@agr.cu.edu.eg

1 Food Science Department, Faculty of Agriculture, Cairo University, Giza, Egypt

2 National Food Institute, Technical University of Denmark, Søltofts Plads 227, 2800 Lyngby, Denmark
Keywords Ohmic heating / Ohmic-ultrasonic heating . Pectinmethylesterase $\cdot$ Phenolic content

\section{Introduction}

Orange juice (OJ) is a good source of bioactive compounds (i.e. vitamin C, phenolics and carotenoids) (Galaverna and Dall'Asta 2014). During storage, OJ can be subject to deteriorative reactions including enzymatic activities, microbial spoilage, vitamin $\mathrm{C}$ degradation, cloud loss and changes in flavor and color, all reactions that lead to loss of product quality. Due to the perishable nature of juices, several technologies have been used to prolong the shelf life (Polydera et al. 2005). Today, recent technologies in food processing either thermal or non-thermal are designed to meet the consumer demands (Williams 1994). NotFrom-Concentrate (NFC) juice is the fruit juice extract without concentration or dilution. Insoluble pulp, skin and seeds are removed before heat treatment of the juice for controlling the microbial load and enzymatic activities (Abedelmaksoud et al. 2018a).

The activity of pectinmethylesterase (PME) results in unwanted layer separation during processing. Conventional heat $(\mathrm{CH})$ treatment reduce PME activity as well as microbial load, however, this treatment can cause loss of nutritional value and produce undesirable flavor in the juice product, especially at temperatures higher than $80{ }^{\circ} \mathrm{C}$ (Giner et al. 2013). Hence, the juice industry searches for mild thermal technologies, which are able to inactivate both enzymes and microorganisms with retention of nutritional value (Chemat et al. 2011).

Hurdle technology is one of the promising technologies in food processing to improve the quality, safety, and stability of food products. Sonication (S) is one of the

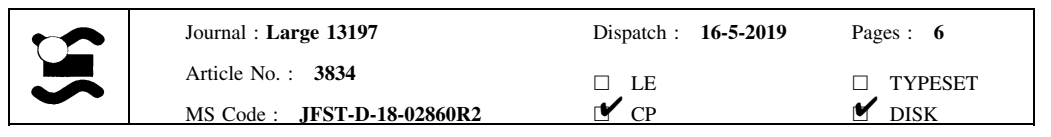


emerging green methods for food processing and preservation. $\mathrm{S}$ is defined as a potential technology acting on reduction of the microbial load in food by $5-\log$ when $\mathrm{S}$ generates cavitation bubbles due to pressure changes (USFDA 2001). S as a substitute to the $\mathrm{CH}$ has the ability to decrease processing time, cost and energy as well as enhanced quality, shelf life and ensured safety of fruit juices (Chemat et al. 2011). However, $S$ alone has limited applications in juices due to its insufficient enzymes and microorganisms inactivation. Therefore, a combination of $\mathrm{S}$ with other technologies with improved efficiencies has been investigated and considered due to the possibility for the application at the industrial scale (Leistner 2000). Previous literature however lack the combination of ohmic heating $(\mathrm{OH})$ with $\mathrm{S}$ as an alternative to the $\mathrm{CH}$ for production and evaluation of NFC orange juice (NFCOJ).

Therefore, the main objectives of this study was to optimize the OS parameters ( $\mathrm{OH}$ temperature and $\mathrm{S}$ time) for inactivation of PME and evaluate the effects on the final NFCOJ. Effects on quality characteristics of the final OJ product at optimum OS conditions were compared to production by other technologies such as $\mathrm{S}$, Thermosonication (TS), $\mathrm{OH}$ and $\mathrm{CH}$.

\section{Materials and methods}

\section{Chemicals}

All chemicals in this study were purchased from (SigmaAldrich Chemical Co., Denmark).

\section{Raw material}

Orange fruits (Citrus sinensis, cv. Navel) purchased from a local supermarket in Copenhagen, Denmark were rinsed and cut into halves. The juice was extracted (Extractor, Krups Citrus Juicer, Spain) and filtrated using a doublelayered muslin cloth. The extracted juice was divided into six groups and subjected to $\mathrm{S}, \mathrm{OS}, \mathrm{TS}, \mathrm{OH}, \mathrm{CH}$ or kept fresh and all groups were rapidly cooled to $4{ }^{\circ} \mathrm{C}$ and stored at $-18^{\circ} \mathrm{C}$ for further analysis.

\section{Processing methods}

\section{Conventional heating}

Orange juice (OJ) $(150 \mathrm{~mL})$ was heated at $95{ }^{\circ} \mathrm{C}$ for $60 \mathrm{~s}$ using a shaker water bath (Julabo, SW22, made in Germany) according to Abedelmaksoud et al. (2018b).
Sonication and Thermosonication ( $S$ and TS)

Samples of $150 \mathrm{~mL}$ OJ was treated with the $\mathrm{S}$ processor of $550 \mathrm{~W}$ at $20 \mathrm{kHz}$ with a 0.5 -inch probe (Sonifier SFX550 Model, Mexico). Treatments at $25{ }^{\circ} \mathrm{C}$ using $100 \%$ power $(550 \mathrm{~W})$ for $8 \mathrm{~min}$ at pulse durations of $5 \mathrm{~s}$ was used. TS was done at $60{ }^{\circ} \mathrm{C}$ at conditions similar to $\mathrm{S}$.

Ohmic heating $(\mathrm{OH})$

The treatment of OJ $(150 \mathrm{~mL})$ by $\mathrm{OH}\left(\right.$ at $42 \mathrm{~V} / \mathrm{cm}, 69{ }^{\circ} \mathrm{C}$ and held for $60 \mathrm{~s}$ ) was conducted according to Demirdöven and Baysal (2014).

Ohmicsonication (OS)

OS was done by a combination of $\mathrm{S}$ and $\mathrm{OH}$ treatments at the obtained optimum parameters, firstly treated by $\mathrm{S}$ for $8 \mathrm{~min}$ at $25^{\circ} \mathrm{C}$ and then directly followed by $\mathrm{OH}$ at $40 \mathrm{~V} /$ $\mathrm{cm}$, to $68{ }^{\circ} \mathrm{C}$ for a holding time of $60 \mathrm{~s}$.

\section{Experimental design and statistical methods}

Response surface methodology (RSM) was used for optimization of OS parameters ( $\mathrm{OH}$ temperature and $\mathrm{S}$ time). Two factors (OH temperature and $\mathrm{S}$ time) with three levels $(-1,0,+1)$, the factorial design $\left(3^{2}\right)$ was used. The $\mathrm{OH}$ temperature and $\mathrm{S}$ time range were $60,65,70{ }^{\circ} \mathrm{C}$ and 2,5 , 8 min, respectively. To describe the effect of parameters, the second-order polynomial model was used (Eq. 1).

$Y=a_{o}+a_{1} x_{1}+a_{2} x_{2}+a_{12} x_{1} x_{2}+a_{11} x_{1}^{2}+a_{22} 1 x_{2}^{2}$

where $Y$ is the \% of PME inactivation, $x_{1}$ is $\mathrm{OH}$ temperature and $x_{2}$ is $\mathrm{S}$ time, ao, $a_{1}, a_{2}, a_{11}, a_{22}$ and $a_{12}$ are regression coefficients for intercept, the linear, the quadratic and interaction term, respectively.

The analysis of variance (ANOVA) for the response was used to find the significant terms in the models (Table S1, supplementary data). Design Expert Version 10.0.6 software was used for the analysis. To optimize the OS parameters, the desirability function method was used. The objective function was to maximize the PME inactivation using desirability function as in Abedelmaksoud et al. (2018b).

To evaluate the variances among different treatments at significance levels $(p \leq 0.05)$, data in Tables 2 was statistically analyzed with one-way ANOVA (Duncan test), using SPSS 13 software (SPSS Inc., Chicago IL, USA).

\section{Physical analysis} ( $\mathrm{L}$, a and $\mathrm{b}$ ) were determined using methods described by

\begin{tabular}{|l|lll|}
\hline & Journal : Large 13197 & Dispatch : 16-5-2019 & Pages : $\mathbf{6}$ \\
Article No. : $\mathbf{3 8 3 4}$ & $\square_{\mathrm{CP}}^{\mathrm{LE}}$ & $\square_{\mathrm{TISK}}^{\mathrm{TYPESET}}$ \\
\hline
\end{tabular}


Abedelmaksoud et al. (2018a). Size distribution particles were detected with the Mastersizer (Model 2000, Malvern, UK).

\section{Chemical analysis}

Vitamin C content was determined using a 2,6dichlorophenol indophenol (DCPIP) visual titration method (Ranganna1986).

Total phenolic content was calorimetrically measured applying Folin-Ciocalteu reagent as described by Abdullakasim et al. (2007) with modifications for microplate reader in Abedelmaksoud et al. (2018b). Results were given as $\mathrm{mg}$ of Gallic acid/100 $\mathrm{mL}$ OJ.

Total carotenoids was measured according to Lee and Castle, (2001) with some modifications based on $5 \mathrm{~mL}$ of OJ (Abedelmaksoud et al. 2018a). Absorbance at $450 \mathrm{~nm}$ of the final supernatant was measured and total carotenoid contents were calculated according to Ritter \& Purcell (1981) using an extinction coefficient of $\beta$-carotene $(\mu \mathrm{g} / \mathrm{g})$, $\mathrm{E}^{1} \%=2505$.

Total flavonoids was measured based on an assay developed by Kim et al. (2003) and the results were expressed as mg catechin equivalents/100 $\mathrm{g}$ OJ.

Hydroxymethyl furfural (HMF) was determined according to a method of Vorlova et al. (2006) using a Vortex Genie II (Scientific Industries, Bohemia, USA) for mixing $1 \mathrm{~mL}$ methanol and $0.5 \mathrm{~mL}$ juice. The centrifuged and filtered $(0.45 \mu \mathrm{m})$ extract was injected $(20 \mu \mathrm{l})$ onto HPLC (Alliance, Waters Company) equipped with a Zorbax Eclipse XDB-C8, $4.6 \times 150 \mathrm{~mm}, 5 \mu \mathrm{m}$ column (Waters, Milford, USA) at $30{ }^{\circ} \mathrm{C}$ using a flow rate of $1 \mathrm{~mL} /$ min and an isocratic mobile phase (10\% methanol in water). UV detection at 285 (2996 diode array detector) using external standard method for quantification of HMF (retention time $3.17 \mathrm{~min}$ ) with a linearity concentration range of $0.01-200 \mathrm{mg} / \mathrm{L}$ based on Empower software (Waters).

Pectinmethylesterase activity was determined according to the method described by Rouse and Atkins (1955) and Ting and Rouseff (1986).

\section{Microbial load}

Total plate count and mold and yeast were determined as in Andrews (1992).

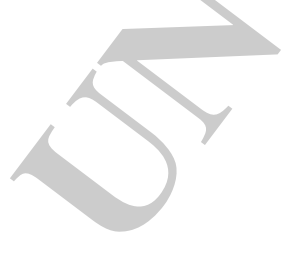

\section{Results and discussion}

\section{Optimization of ohmicsonication (OS) conditions}

Pre-experiments determined optimal $\mathrm{OH}$ temperatures in the range $60-70{ }^{\circ} \mathrm{C}$ and $\mathrm{S}$ time in the range of 2-8 $\mathrm{min}$, where $\mathrm{S}$ time $\geq 8 \mathrm{~min}$ would result in adverse color and vitamin $\mathrm{C}$ changes for $\mathrm{OJ}$ (data not included). Also, increasing the temperature more than $80^{\circ} \mathrm{C}$ caused deterioration of the color and increased juice bubbling leading to juice loss. The voltage gradient of each $\mathrm{OH}$ treatments was selected to be $42 \mathrm{~V} / \mathrm{cm}$ according to optimzation of $\mathrm{OH}$ conditions by Demirdöven and Baysal (2014). RSM set up resulted in PME inhibitions (\%) presented in Table 1.

Optimization of the conditions of OS by applying second order polynomial equation and multiple regression analysis were used to obtain the regression coefficients for independent variables (Eq. 1).

The effect of $\mathrm{OH}$ temperature and $\mathrm{S}$ time on PME activity at $95 \%$ confidence interval (Table S1, supplementary data). The experimental data was fitted and significant with the used model. Insignificant difference between adj- $\mathrm{R}^{2}$ value $(0.968)$ and $\mathrm{R}^{2}$ for PME-this means high degree of correlation between the predicted and experimental values with insignificant lack-of-fit. The model was suitable for describing the $\%$ inactivation of PME within tested experimental ranges.

The positive linear effect of $\mathrm{OH}$ temperature $\left(\chi_{1}\right), \mathrm{S}$ time $\left(\chi_{2}\right)$ were found to be significant for the response variable ( $Y$ : \% inactivation of PME). Also, the interaction $\left(\chi_{1} \chi_{2}\right)$ and the quadratic effect of $\mathrm{OH}$ temperature $\left(\chi_{1}^{2}\right)$ on PME were found to be significant. However, the quadratic of $S$ time $\left(\chi_{2}{ }^{2}\right)$ had an insignificant effect on the PME. The fitted second order polynomial equation are presented as (Eq. 2):

$Y=+93.35+3.94 \chi_{1}+1.76 \chi_{2}-1.00 \chi_{1} \chi_{2}-2.37 \chi_{1}^{2}$

where $\chi_{1}: \mathrm{OH}$ temperature $\left({ }^{\circ} \mathrm{C}\right)$ and $\chi_{2}: \mathrm{S}$ time (min). According to the obtained second order polynomial models, the optimum conditions for OS of NFCOJ was obtained at the maximum PME inactivation by applying desirability function. The obtained optimum parameters were $\mathrm{OH}$ at $68{ }^{\circ} \mathrm{C}$ for $60 \mathrm{~s}$ combined with $\mathrm{S}$ at $550 \mathrm{~W}$ for $8 \mathrm{~min}$, with a PME inactivation of $96 \%$ in NFCOJ (Fig. 1).

\section{Physical, chemical and microbiological contents of fresh and treated NFC orange juice}

Table 2 shows the effects of OS, S, CH, TS and $\mathrm{OH}$ on physical, chemical and microbial load contents of NFCOJ. Compared to fresh orange juice (FOJ), an increase in the $\mathrm{EC}$ was observed for all treatments of $\mathrm{OJ}$ in the following 
Table 1 Experimental design of ohmicsonication (OS) and PME activity in NFC orange juice

Fig. 1 Effect of Ohmicsonication (OS) parameters $(\mathrm{OH}$ temperature and Sonication time) on the PME activity of orange juice $(\mathrm{U} / \mathrm{mL} / \mathrm{min})$-response surface and contour plots

\begin{tabular}{llll}
\hline Run order & OH temperature $\left({ }^{\circ} \mathrm{C}\right), \chi 1$ & Sonication time $(\min ), \chi 2$ & $\%$ inhibition of PME \\
\hline 1 & $65(0)$ & $5(0)$ & 93.53 \\
2 & $65(0)$ & $5(0)$ & 93.40 \\
3 & $70(+1)$ & $5(0)$ & 94.93 \\
4 & $70(+1)$ & $2(-1)$ & 93.88 \\
5 & $60(-1)$ & $5(0)$ & 87.98 \\
6 & $65(0)$ & $2(-1)$ & 92.04 \\
7 & $70(+1)$ & $8(+1)$ & 95.94 \\
8 & $60(-1)$ & $2(-1)$ & 83.53 \\
9 & $60(-1)$ & $8(+1)$ & 89.61 \\
10 & $65(0)$ & $8(+1)$ & 94.44 \\
\hline
\end{tabular}

In the 2nd and 3rd column: the coded values of the test parameters are in parenthesis and the real (uncoded) values are outside the parenthesis, $P M E$ pectinmethylesterase

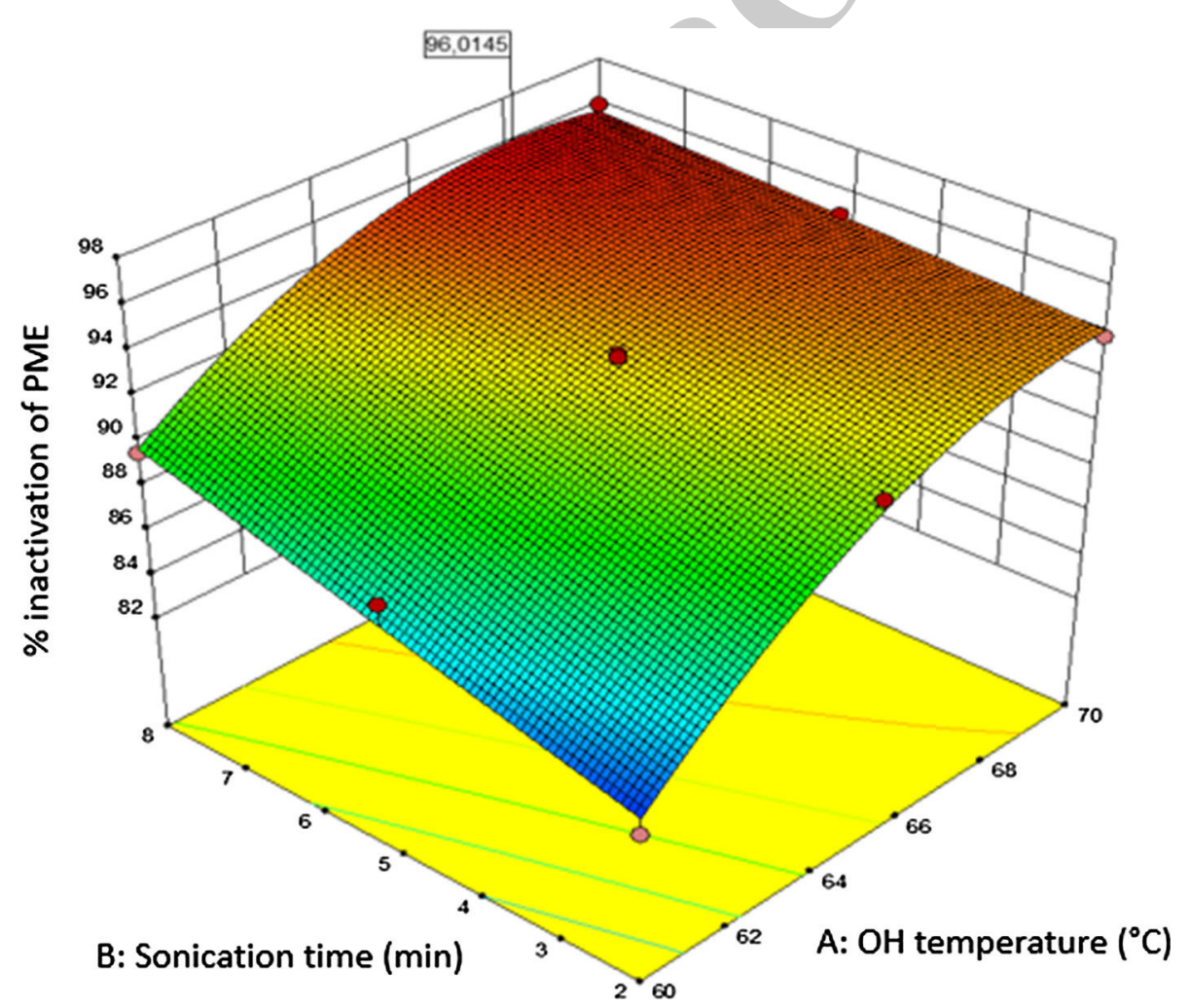

order: $\mathrm{OS}>\mathrm{TS}>\mathrm{S}>\mathrm{OH}>\mathrm{CH}$. Increased EC of juice, especially for $\mathrm{S}$ (S, TS and OS) might be attributed to the agitated enhanced release of minerals and bioactive components as well as increased ionic mobility (Zou and Jiang 2016).

A lower ADS, indicating a more homogenous juice, was observed in the sonicated samples (OS, S, TS) compared to non-sonicated samples (FOJ, $\mathrm{CH}$ and $\mathrm{OH}$ ) (Table 2). This is due to the effect of cavitational collapse by $\mathrm{S}$ and the resulting particle size reduction (Franco et al. 2004).

For color values ( $\mathrm{L}, \mathrm{a}$ and $\mathrm{b}$ ) the $\mathrm{L} *$ value was increased by $\mathrm{S}$, TS and OS, while insignificantly changed by $\mathrm{CH}$ and
$\mathrm{OH}$ treatments. The $\mathrm{a}^{*}$ and $\mathrm{b}^{*}$ were significantly increased for all treatments $(\mathrm{OS}>\mathrm{TS}>\mathrm{S}>\mathrm{OH}>\mathrm{CH})$ compared to FOJ, attributed to chemical changes by thermal treatments (Bhale 2004). Increased color values by $\mathrm{S}$ could be due to less enzymatic color changes and an increased phenolic and carotenoid condensation reducing their oxidation as explained by Tiwari et al. (2008).

Vitamin $\mathrm{C}$ were significantly decreased for all treatments when compared to FOJ $(52.77 \mathrm{mg} / 100 \mathrm{~mL})$ and followed the order $\mathrm{S}>\mathrm{OS}>\mathrm{OH}>\mathrm{TS}>\mathrm{CH}$. S alone was not efficient in the inactivation of PME and microorganisms (Table 2) and therefore not accepted for

\begin{tabular}{|l|lll|}
\hline Journal : Large 13197 & Dispatch : 16-5-2019 & Pages : $\mathbf{6}$ \\
Article No. : $\mathbf{3 8 3 4}$ & $\square$ & $\square$ TYPESET \\
MS Code : JFST-D-18-02860R2 & $\sim_{\text {CP }}$ & $\checkmark$ DISK \\
\hline
\end{tabular}


Table 2 Physical, chemical and microbiological contents of fresh and processed NFC orange juice during different treatments of NFC orange juice

\begin{tabular}{|c|c|c|c|c|c|c|}
\hline Parameters & FOJ & $S$ & $\mathrm{CH}$ & $\mathrm{TS}$ & $\mathrm{OH}$ & OS \\
\hline $\mathrm{EC}(\mathrm{s} / \mathrm{m})$ & $0.272 \pm 0.003 \mathrm{c}$ & $0.293 \pm 0.004 \mathrm{ab}$ & $0.282 \pm 0.004 \mathrm{bc}$ & $0.297 \pm 0.007 \mathrm{ab}$ & $0.286 \pm 0.004 a b c$ & $0.303 \pm 0.009 a$ \\
\hline Cloud value (A) & $0.253 \pm 0.07 \mathrm{c}$ & $0.274 \pm 0.003 \mathrm{c}$ & $0.970 \pm 0.005 b$ & $0.946 \pm 0.008 b$ & $0.994 \pm 0.003 b$ & $1.240 \pm 0.04 \mathrm{a}$ \\
\hline $\operatorname{ADS}(\mu \mathrm{m})$ & $3.970 \pm 0.04 b$ & $0.304 \pm 0.01 \mathrm{~d}$ & $2.096 \pm 0.02 \mathrm{c}$ & $0.290 \pm 0.01 \mathrm{f}$ & $4.191 \pm 0.02 \mathrm{a}$ & $0.323 \pm 0.01 \mathrm{e}$ \\
\hline $\mathrm{L}^{*}$ & $42.57 \pm 0.02 \mathrm{~d}$ & $44.71 \pm 0.09 \mathrm{c}$ & $42.63 \pm 0.03 \mathrm{~d}$ & $46.03 \pm 0.08 b$ & $42.77 \pm 0.04 \mathrm{~d}$ & $46.95 \pm 0.29 \mathrm{a}$ \\
\hline$a^{*}$ & $-6.66 \pm 0.02 \mathrm{e}$ & $-5.15 \pm 0.04 b$ & $-6.08 \pm 0.02 \mathrm{~d}$ & $-4.96 \pm 0.03 \mathrm{~cd}$ & $-5.83 \pm 0.02 \mathrm{~cd}$ & $-4.73 \pm 0.01 \mathrm{a}$ \\
\hline$b^{*}$ & $9.65 \pm 0.02 \mathrm{e}$ & $10.36 \pm 0.14 \mathrm{c}$ & $9.95 \pm 0.06 \mathrm{f}$ & $11.33 \pm 0.02 \mathrm{a}$ & $10.15 \pm 0.05 \mathrm{~d}$ & $10.76 \pm 0.03 b$ \\
\hline$\Delta \mathrm{E}$ & - & $2.72 \pm 0.27 \mathrm{c}$ & $0.65 \pm 0.02 \mathrm{e}$ & $4.21 \pm 0.04 \mathrm{a}$ & $0.99 \pm 0.03 d$ & $4.91 \pm 0.28 b$ \\
\hline Vitamin C (mg/100 mL) & $52.77 \pm 0.14 \mathrm{a}$ & $48.22 \pm 0.22 b$ & $43.58 \pm 0.25 \mathrm{f}$ & $46.08 \pm 0.16 \mathrm{e}$ & $47.22 \pm 0.18 \mathrm{~d}$ & $47.62 \pm 0.19 \mathrm{c}$ \\
\hline $\begin{array}{l}\text { Total carotenoids }(\mu \mathrm{g} / \\
100 \mathrm{~g})\end{array}$ & $1270 \pm 13.5 b$ & $1308 \pm 3.22 \mathrm{a}$ & $982 \pm 8.16 f$ & $1107 \pm 7.62 \mathrm{e}$ & $1126 \pm 5.54 \mathrm{~d}$ & $1183 \pm 8.73 c$ \\
\hline $\begin{array}{l}\text { Total flavonoids (mg/ } \\
100 \mathrm{~mL})\end{array}$ & $20.01 \pm 0.39 \mathrm{c}$ & $21.80 \pm 0.47 b$ & $20.32 \pm 0.62 c$ & $22.27 \pm 0.24 \mathrm{a}$ & $20.58 \pm 1.38 c$ & $22.83 \pm 0.31 \mathrm{a}$ \\
\hline $\begin{array}{l}\text { Total phenolic }(\mathrm{mg} / \\
100 \mathrm{~mL})\end{array}$ & $37.47 \pm 0.13 \mathrm{e}$ & $42.06 \pm 0.22 \mathrm{a}$ & $37.61 \pm 0.26 \mathrm{e}$ & 39. & $38.22 \pm 0.09 \mathrm{~d}$ & $40.73 \pm 0.69 b$ \\
\hline HMF (mg/L) & nd & $0.73 \pm 0.02 \mathrm{c}$ & $2.72 \pm 0.02 \mathrm{a}$ & $1.37 \pm 0.18 b$ & $0.95 \pm 0.21 \mathrm{c}$ & $0.90 \pm 0.08 \mathrm{c}$ \\
\hline PME (U/mL/min) & $47.57 \pm 0.6 \mathrm{a}$ & $33.55 \pm 0.4 b$ & $5.38 \pm 0.3 \mathrm{c}$ & $4.62 \pm 0.2 d$ & $2.21 \pm 0.1 \mathrm{e}$ & $1.93 \pm 0.3 \mathrm{f}$ \\
\hline $\begin{array}{l}\text { Total plate count (log cfu/ } \\
\mathrm{mL})\end{array}$ & $2.27 \pm 0.5$ & nd & nd & nd & nd & nd \\
\hline $\begin{array}{l}\text { Mold and yeast (log cfu/ } \\
\mathrm{mL})\end{array}$ & $1.92 \pm 0.3$ & nd & nd & $d$ & nd & nd \\
\hline
\end{tabular}

Different letters $(\mathrm{a}, \mathrm{b}, \mathrm{c})$ mean statistical significant difference $(\mathrm{p}<0.05)$; the results represent the mean $\pm \mathrm{SD}$

$F O J$ fresh orange juice, $S$ sonication, $C H$ conventional heating, $T S$ thermosonication, $O H$ ohmic heating, $O S$ ohmicsonication, $E C$ electric conductivity, $A D S$ average droplet sizes $(\mu \mathrm{m}), H M F$ hydroxymethylfurforal, $P M E$ pectinmethylesterase

processing of OJ. The vitamin $\mathrm{C}$ reduction was attributed to chemical decomposition due to both temperature and time of processing correlating with the findings by Demirdöven and Baysal (2014), who reported a decrease of vitamin C in the $\mathrm{OH}$ and $\mathrm{CH}$ treatments compared to the FOJ.

A significant increase in the total carotenoids of $\mathrm{OJ}$ for $\mathrm{S}$ $(1308 \mu \mathrm{g} / 100 \mathrm{~g})$ correlates with cell wall disruption causing more free carotenoids in the juice stated by Plaza et al. (2011). Also, Abid et al. (2014) observed increased carotenoid levels with S. Oxygen, light, metals and enzyme availability as well as heat application led to loss of carotenoids for OS, TS, OH and CH (Table 2), which is in agreement with previous reports on carotenoid stability (Rawson et al. 2011; Esteve et al. 2009).

Total phenolic content (TPC) of OJ were significantly increased in $\mathrm{S}, \mathrm{OS}$, TS and $\mathrm{OH}$ treatments $(\mathrm{S}>\mathrm{OS}>$ $\mathrm{TS}>\mathrm{OH}$ ) compared to FOJ, while insignificant increase was found for $\mathrm{CH}$ treated sample (Table 2). Heating (during $\mathrm{CH}$ and $\mathrm{OH}$ treatments) might increase the extractability of TPC due to breakdown of the interaction between proteins and polyphenols (Girgin and El 2015). Previous reports explain TPC release during $\mathrm{OH}$ induced by the alternating current (Roy et al. 2009), while the increased release of TPC during $\mathrm{S}$ is due to the cavitation phenomenon resulting in breakdown of the cell wall based on liquid pressure changes during $\mathrm{S}$ treatment, thus increasing the availability of phenols in the juice (Abid et al. 2014).

OS treated juice contained the lowest value of HMF $(0.90 \mathrm{mg} / \mathrm{L})$ followed by $\mathrm{OH}(0.95 \mathrm{mg} / \mathrm{L})$ and $\mathrm{TS}$ $(1.37 \mathrm{mg} / \mathrm{L})$ with highest values in $\mathrm{CH}$ treated juice $(2.72 \mathrm{mg} / \mathrm{L})$. The presence of HMF in foods (containing carbohydrates in an acidic environment) is a result of high heat treatment $\left(\mathrm{T}>80^{\circ} \mathrm{C}\right)$ and inappropriate and longterm storage. As expected, levels for HMF varies e.g. from not detected to $27 \mathrm{mg} / \mathrm{L}$ in fruit juices (Vorlova et al. 2006).

All treatments showed a significant increase in cloud value with the highest value indicating highest cloud stability and PME inhibition obtained for OS (Table 2). Increased parameters were attributed to the combined effects of heat and voltage gradient (which might remove the metallic prosthetic groups present in the PME) (Castro et al. 2004) and cavitation on enzyme activity, causing a decreased layer separation.

After treatment of OJ sample by $\mathrm{S}, \mathrm{CH}, \mathrm{TS}, \mathrm{OH}$ and $\mathrm{OS}$ no microbial growth neither total plate count nor mold or yeast were detected (Table 2).

\begin{tabular}{|c|c|c|c|}
\hline Journal : Large 13197 & Dispatch : & 16-5-2019 & Pages: 6 \\
\hline $\begin{array}{l}\text { Article No. : } \mathbf{3 8 3 4} \\
\text { MS Code : } \quad \text { JFST-D-18-02860R2 }\end{array}$ & $\begin{array}{l}\square \\
\boldsymbol{V}_{\mathrm{CP}}^{\mathrm{LE}}\end{array}$ & & $\begin{array}{ll}\square & \text { TYPESET } \\
\boldsymbol{V} & \text { DISK }\end{array}$ \\
\hline
\end{tabular}




\section{Conclusion}

308 The use of OS result in an improved quality of OJ com309 pared to other treatments. The highest inactivation of PME 310 activity with no microbial load as well as highest retention 311 of vitamin $\mathrm{C}$, carotenoids, phenolics, and flavonoids were 312 obtained with OS compared to the other treatments $(\mathrm{OH}$, 313 TS, S and $\mathrm{CH}$ ). In addition, OS treatment resulted in 314 increased EC, cloud value and color values. S treatment 315 alone was not sufficient for inactivation of PME at lower 316 temperature. Overall, OS improved the quality of OJ in 317 laboratory scale compared to other treatments and can be a 318 potential technology for pasteurization of juice. An appli319 cation in a pilot plant or large scale could be interesting and 32( AQ3 needs to be considered for further studies.

\section{References}

Acknowledgements Tarek Abedelmaksoud would like to thank The Danish Agency for Higher Education for a research grant as a guest Ph.D. Student for one year in Food Production Engineering Research Group, Technical University of Denmark. Authors would like to thank Anette Bysted and Inge Holmberg at DTU for support on Sugars, HMF and carotenoids analysis.

Abdullakasim P, Songchitsomboon S, Techagumpuch M et al (2007) Antioxidant capacity, total phenolics and sugar content of selected Thai health beverages. Int J Food Sci Nutr 58:77-85

Abedelmaksoud TG, Mohsen SM, Duedahl-Olesen L et al (2018a) Effect of ohmic heating parameters on inactivation of enzymes and quality of not-from-concentrate mango juice. Asian J Sci Res 11(3):383-392

Abedelmaksoud TG, Mohsen SM, Duedahl-Olesen L et al (2018b) Optimization of ohmic heating parameters for polyphenoloxidase inactivation in not-from-concentrate elstar apple juice using RSM. J Food Sci Technol 55(7):2420-2428

Abid M, Jabbar S, Wu T et al (2014) Sonication enhances polyphenolic compounds, sugars, carotenoids and mineral elements of apple juice. Ultrason Sonochemistry 21:93-97

Andrews W (1992) Manuals of food quality control, microbiological analysis, (chapter 4). Food and Drug Administration Washington, DC, USA.(FAO Food and Nutrition Paper, 14/4 Rev. 1, FAO Consultant), M-82. ISBN: 92-5-103189-4

Bhale SD (2004) Effect of ohmic heating on color, rehydration and textural characteristics of fresh carrot cubes. LSU Master's Theses. p 3918. https://digitalcommons.1su.edu/gradschool_the ses/3918

Castro I, Macedo B, Teixeira JA, Vicente AA (2004) The effect of electric field on important food-processing enzymes: comparison of inactivation kinetics under conventional and ohmic heating. J Food Sci 69:696-701

Chemat F, Zill-e-Huma, Khan MK (2011) Applications of ultrasound in food technology: processing, preservation and extraction. Ultrason Sonochemistry 18:813-835

Demirdöven A, Baysal T (2014) Optimization of ohmic heating applications for pectin methylesterase inactivation in orange juice. J Food Sci Technol 51:1817-1826

Esteve MJ, Barba FJ, Palop S, Frígola A (2009) The effects of nonthermal processing on carotenoids in orange juice. Czech J Food Sci 27:S304-S306
Franco F, Pérez-Maqueda LA, Pérez-Rodríguez JL (2004) The effect of ultrasound on the particle size and structural disorder of a well-ordered kaolinite. J Colloid Interface Sci 274:107-117

Galaverna G, Dall'Asta C (2014) Production processes of orange juice and effects on antioxidant components. In: Preedy VR (ed) Processing and impact on antioxidants in beverages. Elsevier, Amsterdam, pp 203-214

Giner MJ, Hizarci Õ, Martí N et al (2013) Novel approaches to reduce Brown Pigment Formation and Color Changes in Thermal Pasteurized Tomato Juice. Euro Food Res Technol 236:507-515

Girgin N, El SN (2015) Effects of cooking on in vitro sinigrin bioaccessibility, total phenols, antioxidant and antimutagenic activity of cauliflower (Brassica oleraceae L. vâr. Botrytis). J Food Compos Anal 37:119-127

Kim DO, Jeong SW, Lee CY (2003) Antioxidant capacity of phenolic phytochemicals from various cultivars of plums. Food Chem 81:321-326

Lee HS, Castle WS (2001) Seasonal change of carotenoid pigments and color in Hamlin, Earlygold, and Budd Blood orange juices. J Agric Food Chem 49:877-882

Leistner I (2000) Basic aspects of food preservation by hurdle technology. Inter J Food Micro 55:181-186

Plaza L, Sánchez-Moreno C, De Ancos B et al (2011) Carotenoid and flavanone content during refrigerated storage of orange juice processed by high-pressure, pulsed electric fields and low pasteurization, LWT - Food Sci Technol 44:834-839

Polydera AC, Stoforos NG, Taoukis PS (2005) Quality degradation kinetics of pasteurised and high pressure processed fresh navel orange juice: nutritional parameters and shelf life. Technol Emerg Sci Food Innov 6(1):1-9

Ranganna S (1986) Handbook of analysis and quality control for fruit and vegetable products. 2sd. Chapter 5 vitamins, pp 105-107. ISBN-13: 978-0-07-451861-9

Rawson AB, Tiwari A, Patras N et al (2011) Effect of thermosonication on bioactive compounds in watermelon juice. Food Res Inter 44:1168-1173

Ritter E, Purcell AE (1981) Carotenoid analytical methods. In: Bavernfeind JC (ed) Carotenoids as colorants and vitamin A precursors. Academic Press, New York, pp 815-883

Rouse AH, Atkins CD (1955) Pectinesterase and pectin in commercial citrus juices as determined by methods used at the Citrus Experiment Station. Calif Agric Exp Stn Bull 570:1-9

Roy MK, Juneja LR, Isobe S, Tsushida T (2009) Steam processed broccoli (Brassica oleracea) has higher antioxidant activity in chemical and cellular assay systems. Food Chem 114:263-269

Ting SV, Rouseff RL (1986) Measurement of quality for grades and standards. Citrus fruits and their products: analysis and technology. Marcel Dekker, Inc., New York, pp 35-65

USFDA (2001) Hazard analysis and critical control point (HACCP) procedures for the safe and sanitary processing and importing of juices: final rule. Fed Reg 66:6138-6202

Vorlova L, Borkovcová I, Kalábová K, Večerek V (2006) Hydroxymethylfurfural contents in foodstuffs determined by HPLC method. J Food Nutr Res 45: 34-38

Williams A (1994) New technologies in food preservation and processing: part II. Nutr Food Sci 94(1):20-23

Zou Y, Jiang A (2016) Effect of ultrasound treatment on quality and microbial load of carrot juice. Food Sci Technol Campinas 36:111-115

Publisher's Note Springer Nature remains neutral with regard to jurisdictional claims in published maps and institutional affiliations.

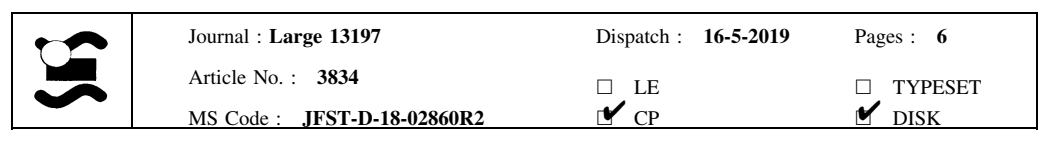


Journal : 13197

Article : $\mathbf{3 8 3 4}$

\section{Author Query Form}

\section{Please ensure you fill out your response to the queries raised below and return this form along with your corrections}

\section{Dear Author}

During the process of typesetting your article, the following queries have arisen. Please check your typeset proof carefully against the queries listed below and mark the necessary changes either directly on the proof/online grid or in the 'Author's response' area provided below

\begin{tabular}{|l|l|l|}
\hline Query & Details Required & Author's Response \\
\hline AQ1 & $\begin{array}{l}\text { Please confirm if the author names are presented accurately and in the correct sequence (given name, } \\
\text { middle name/initial, family name). Author 1 Given name: [Tarek Gamal] Last name [Abedelmaksoud]. } \\
\text { Author 2 Given name: [Sobhy Mohamed] Last name [Mohsen]. Author 4 Given name: [Mohamed } \\
\text { Mohamed] Last name [Elnikeety]. Author 5 Given name: [Aberham Hailu] Last name [Feyissa]. Also, } \\
\text { kindly confirm the details in the metadata are correct. }\end{array}$ & $\begin{array}{l}\text { Reference Tiwari et al. (2008) is cited in text but not provided in the reference list. Please provide } \\
\text { references in the list or delete these citations. }\end{array}$ \\
\hline AQ2 & Please confirm the section headings are correctly identified. & \\
\hline AQ4 & Please provide author initials for the reference Chemat et al. (2011). & \\
\hline
\end{tabular}

